serie ICT Technologies in Europe: A Study of Technological Diffusion and Economic Growth under Network Theory 
Los documentos de trabajo del Ivie ofrecen un avance de los resultados de las investigaciones económicas en curso, con objeto de generar un proceso de discusión previo a su remisión a las revistas científicas. Al publicar este documento de trabajo, el Ivie no asume responsabilidad sobre su contenido.

Ivie working papers offer in advance the results of economic research under way in order to encourage a discussion process before sending them to scientific journals for their final publication. Ivie's decision to publish this working paper does not imply any responsibility for its content.

La Serie AD es continuadora de la labor iniciada por el Departamento de Fundamentos de Análisis Económico de la Universidad de Alicante en su colección "A DISCUSIÓN" y difunde trabajos de marcado contenido teórico. Esta serie es coordinada por Carmen Herrero.

The AD series, coordinated by Carmen Herrero, is a continuation of the work initiated by the Department of Economic Analysis of the Universidad de Alicante in its collection "A DISCUSIÓN", providing and distributing papers marked by their theoretical content.

Todos los documentos de trabajo están disponibles de forma gratuita en la web del Ivie http:/ / www.ivie.es, así como las instrucciones para los autores que desean publicar en nuestras series.

Working papers can be downloaded free of charge from the Ivie website http://www.ivie.es, as well as the instructions for authors who are interested in publishing in our series.

Versión: diciembre 2012 / Version: December 2012

Edita / Published by:

Instituto Valenciano de Investigaciones Económicas, S.A.

C/ Guardia Civil, 22 esc. 2 1o - 46020 Valencia (Spain) 
WP-AD 2012-21

\title{
ICT technologies in Europe: A study of technological diffusion and economic growth under network theory
}

\author{
Ana Salomé García and María Rosalía Vicente*
}

\begin{abstract}
The sector of Information and Communication Technologies is one of the key instruments for the development of an economy. The literature emphasizes its capacity for both increasing productivity and generating new sources of income and wealth (Jorgenson, 2001; Colecchia and Schereyer, 2002; among others). Traditionally studies on the ICT sector have focused on the analysis of its economic impact, but not on its capacity as a "bridge" of information and knowledge flows across the economic network. Following Burt's approach (1992) about structural holes, the organization of the economic network defines where and for whom new opportunities lie. The structural hole methodology allows to analyze the capacity of the ICT sector as an enabler of technological diffusion and innovation. Our results show that the European ICT sector not only is important for its intermediary role in the flow of information across the economic network, but also for its low level of dependency on other sectors.
\end{abstract}

Keywords: Information and Communication Technologies (ICT); diffusion; innovation; networks; information and knowledge flows.

JEL classification numbers: C67, O14.

* University of Oviedo. Corresponding author: A.S. García, asgarcia@uniovi.es. 


\section{Introduction}

Over the last decade a large number of studies have tried to unveil the role of Information and Communication Technologies (ICT) in economic development and productivity growth (Brynjolffson and Hitt, 2000; Jorgenson and Stiroh, 2000; Oliner and Sichel, 2000, 2002; Colecchia and Schreyer, 2002; for a recent survey see Kretschmer, 2012). The potential of ICT relies in the fact that they are "general purpose technologies" (Bresnahan and Trajtenberg, 1995) whose main features are their fast path of technological improvement, their "pervasiveness" across the full economy and their role as innovation-enablers.

Thus, ICT facilitate the creation of new knowledge and its faster diffusion through more efficient processes of information transmission (both within and between firms) (Kretschmer, 2012), the development of closer links between customers, suppliers and collaborative partners and the reduction of geographical barriers (Friedman, 2005). All these have lead to an increasingly networked economy in which information is a key economic factor (Castells, 2000).

Within this context, this paper analyzes the extent to which the ICT sector acts as a "bridge" that facilitates the spread of "relevant" information and knowledge across the productive sectors of the economic network. In order to assess the relevance of information flows between sectors, this paper follows Burt's approach on structural holes (Burt, 1992) in the framework of input-output (IO) methodology and network theory. To authors' knowledge this is the first time to apply such approach to evaluate the role of the ICT sector in the economy, since previous research have relied on growth accounting exercises and econometric estimations of the production function (ICTNET, 2011). Empirical evidence is drawn from data on input-output tables for the European Union over the period 2000-2007.

\section{Methodology: Structural holes}

Following Burt's approach (1992), the organization of the economic network defines where new opportunities lie and who can benefit from it. Proximity and connection imply different intermediation degrees that can create advantages of access, time and exclusivity for certain sectors.

In this sense, inter-sector relationships do not provide the same information and the same opportunities. If each productive relation puts the sector in contact with the same sectors through other linkages, it is more likely that the information generated in the network will be less varied than when the network is sparse. Thus, we can say that these productive relations are "redundant" as they involve the same sectors and then supply the same information. New 
ideas and opportunities are around the "bridge relationships" that connect branches of different sector groups. Hence, this kind of non-redundant links allows obtaining benefits: sectors, which operate as bridges, make possible the flow of varied information and facilitate the diffusion of ideas, knowledge and innovation. Therefore, the economic structure can create opportunities for certain sectors in these areas called structural holes. In sum, a structural hole is “a relationship of non-redundancy between two nodes” (Burt, 1992).

The presence of structural holes in "real economic" networks is far from unusual (García, Morillas and Ramos, 2010). In fact, this concept can be applied to identify the points of fragmentation in the production process. Economists have largely studied fragmentation processes (also called vertical specialization slicing-up the value chain, or outsourcing, among others) (Humphrey and Schmitz 2002; Jones and Kierzkowski 2005) and have found two key elements in them: the current trends to lowering service-link costs and the increase in the scale of production (Jones and Kierzkowski 2005). As Hummels et al. (2001) point out; there are various reasons for this vertical tendency "one possibility is that technological shocks have led to the fragmentation of production. These shocks may include changes in production technique such as an increase in the number of production stages or shocks that make it easier to separate existing stages of production. A second possibility is that reductions in the cost of moving goods have driven the increase in vertical specialization". The concept of structural holes has been successfully applied in input-output field with the aim of study fragmentation activities and innovation diffusion (Garcia et al., 2010).

The determination of structural holes is based on the level of non-redudant relations. The relative indicator of the diversity in network connections is called efficiency (Burt, 1992) and can be calculated as the difference in relative terms between network size $\left(\mathrm{N}_{\mathrm{i}}\right)$ and level of redundancy $\left(\mathrm{R}_{\mathrm{i}(\mathrm{j})}\right)$ :

$$
\begin{gathered}
E_{i}=\frac{T E_{i}}{N_{i}}=\frac{N_{i}-\sum_{j} R_{i(j)}}{N_{i}} ; q \neq i, j \\
0 \leq E_{i}<1
\end{gathered}
$$

where the knowledge obtained by a sector $i$ is described as redundant if this sector $i$ has an important relation-in terms of quantity-with another sector $q$, which simultaneously maintains relevant productive transactions with sector $j$. A sector i evaluate the extent to which a sector $\mathrm{j}$ is redundant with your other sectoral contacts. Given this, the indicator of redundancy can be written as (Burt 1992; Borgatti, 1997): 


$$
\mathrm{R}_{\mathrm{i}(\mathrm{j})}=\sum_{\mathrm{q}} \mathrm{p}_{\mathrm{iq}} \mathrm{m}_{\mathrm{jq}}
$$

where $\mathrm{p}_{\mathrm{iq}}$ shows the proportion of economic direct relations between sectors I and q with respect the sum of i's relations and $m_{j q}$ represents the marginal intensity of linkage sector $j$ 's relation with sector $q$.

Efficiency values $\left(E_{i}\right)$ near to one indicate a high level of efficiency, that is, a high number of non-redundant contacts, whereas numbers close to zero point out a high degree of redundancy and therefore a low level of efficiency in the capacity for information access.

Complementary to the efficiency study it is interesting to analyze the degree of dependence between sectors. If a high-efficiency sector strongly depends on other, the benefits of information transmission can be limited since the economic difficulties of the latter can influence the former. In order to take account of the restrictions in the network, the following aggregated constraint index can be used (Burt, 1992):

$$
\mathrm{C}_{\mathrm{i}}=\sum_{\mathrm{j}} \mathrm{c}_{\mathrm{ij}}
$$

where

$$
\mathrm{c}_{\mathrm{ij}}=\left(\mathrm{p}_{\mathrm{ij}}^{*}+\sum_{\mathrm{q}} \mathrm{p}_{\mathrm{iq}}^{*} \mathrm{p}_{\mathrm{qj}}^{*}\right)^{2} ; \mathrm{q} \neq \mathrm{i}, \mathrm{j}
$$

$\mathrm{p}_{\mathrm{ij}}^{*}$ is the proportional strength of $\mathrm{i}$ relationship with $\mathrm{j}, \mathrm{p}_{\mathrm{iq}}^{*}$ the weight of the relationship of sector $\mathrm{i}$ with respect to $\mathrm{q}$ and $\mathrm{p}_{\mathrm{qj}}^{*}$ the weight of the relationship of sector $\mathrm{q}$ with respect to $\mathrm{j}$. The first term of sum describe the direct efforts to establish the relationships between sectors $\mathrm{i}$ and $\mathrm{j}$. The second term the undirected efforts described above $\left(\mathrm{U}_{\mathrm{i}}\right)$. .

Network constraints vary along the following three network dimensions: size, density and hierarchy. Constraints are high if a sector "has few links and those flows are connected to one another either directly (as in a dense network) or through a central and mutual contact (as in a hierarchical network)" (Burt, 1998). The hierarchy degree $\left(\mathrm{H}_{\mathrm{i}}\right)$ - the extent to which the redundancy can be traced to a single contact in the network- is measured by the ColemanTheil inequality index (Burt, 1992). 


\section{European ICT Sector}

The described methodology has been applied to the analysis of the ICT sector in the European Union. The statistical information comes from the last input-output tables published by Eurostat and refers to the years 2000, 2005 and 2007. This methodology allows analyzing the capacity of the economy for technological diffusion, for enhancing innovation and creating new market opportunities.

Hence, on the basis of input-output tables, we approach the extent to which the ICT sector is a key element for economic growth. Its role is compared with that of the rest of the industries, identifying differences in European technological capacities.

In order to make these cross-country comparisons, it is essential to work with a homogeneous and widely accepted definition of the ICT sector. In this paper, the definition of ICT sector follows the international standards set, for the first time, by the Organization of Economic Cooperation and Development (OECD) in 1998. Such 1998 definition was subject to review in 2002 with minor changes. Table $n^{0} 1$ shows ICT sector definition (2002), based on the ISIC Rev. 3 classification of activities (OECD, 2003).

A new definition of the ICT sector was agreed in 2007 in order to update the exhaustive list of ICT activities on the basis of the ISIC Rev. classification 4 (OECD, 2011).

\section{Table $n^{0}$ 1. The ICT sector definition}

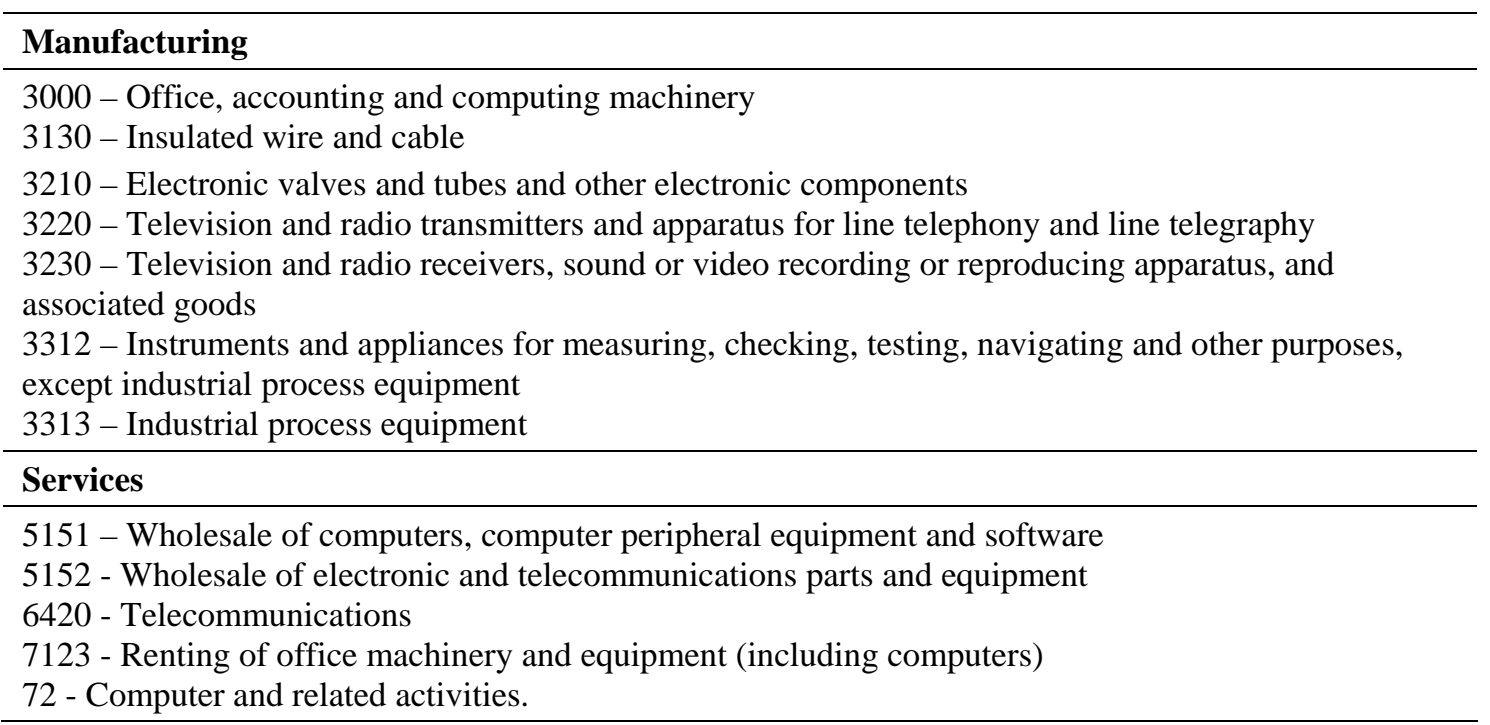


The 2002 definition is used in this paper given that the classification of activities in the available input-output tables relies on ISIC Rev. 3 classification. In particular, the following the ICT activities are considered: Office, accounting and computing machinery, Electrical machinery and apparatus, Radio, television and communication equipment, Medical precision and optical instruments, Wholesaling of machinery, equipment and supplies, Renting of office machinery and equipment, Computer and related activities.

Table $n^{\circ} 2$ shows the results on the levels of efficiency and dependence for the ICT sector (See annex for non ICT sectors).

Table $\mathbf{n}^{\circ} 2$. Structural holes ICT sectors

\begin{tabular}{|c|c|c|c|c|c|c|c|c|c|c|c|c|}
\hline & \multicolumn{4}{|c|}{2007} & \multicolumn{4}{|c|}{2005} & \multicolumn{4}{|c|}{2000} \\
\hline & $\mathbf{E i}$ & $\mathbf{C i}$ & $\mathbf{H i}$ & Ui & $\mathbf{E i}$ & $\mathbf{C i}$ & Hi & Ui & $\mathbf{E i}$ & $\mathbf{C i}$ & $\mathbf{H i}$ & Ui \\
\hline $\begin{array}{l}\text { Office, accounting and } \\
\text { computing machinery }\end{array}$ & 0.779 & 0.176 & 0.388 & 0.993 & 0.776 & 0.174 & 0.382 & 0.993 & 0.782 & 0.174 & 0.383 & 0.988 \\
\hline $\begin{array}{l}\text { Electrical machinery and } \\
\text { apparatus }\end{array}$ & 0.797 & 0.168 & 0.337 & 0.968 & 0.798 & 0.166 & 0.329 & 0.969 & 0.807 & 0.16 & 0.319 & 0.964 \\
\hline $\begin{array}{l}\text { Radio, television and } \\
\text { communication equipment }\end{array}$ & 0.806 & 0.157 & 0.32 & 0.981 & 0.808 & 0.158 & 0.322 & 0.98 & 0.807 & 0.157 & 0.321 & 0.971 \\
\hline $\begin{array}{l}\text { Medical, precision and } \\
\text { optical instruments }\end{array}$ & 0.812 & 0.153 & 0.303 & 0.982 & 0.815 & 0.153 & 0.307 & 0.982 & 0.82 & 0.148 & 0.287 & 0.981 \\
\hline $\begin{array}{l}\text { Wholesaling of machinery, } \\
\text { equipment and supplies }\end{array}$ & 0.81 & 0.132 & 0.292 & 0.927 & 0.809 & 0.132 & 0.299 & 0.924 & 0.814 & 0.128 & 0.287 & 0.919 \\
\hline Telecommunications & 0.778 & 0.172 & 0.4 & 0.967 & 0.78 & 0.171 & 0.392 & 0.963 & 0.787 & 0.163 & 0.37 & 0.963 \\
\hline $\begin{array}{l}\text { Renting of office machinery } \\
\text { and equipment }\end{array}$ & 0.784 & 0.153 & 0.333 & 0.981 & 0.786 & 0.151 & 0.324 & 0.982 & 0.787 & 0.15 & 0.322 & 0.982 \\
\hline $\begin{array}{l}\text { Computer and related } \\
\text { activities }\end{array}$ & 0.755 & 0.189 & 0.451 & 0.968 & 0.757 & 0.19 & 0.442 & 0.969 & 0.763 & 0.182 & 0.427 & 0.972 \\
\hline MEAN ICT SECTORS & 0.790 & 0.163 & 0.353 & 0.971 & 0.791 & 0.162 & 0.350 & 0.970 & 0.796 & 0.158 & 0.340 & 0.968 \\
\hline MEAN NON ICT SECTORS & 0.798 & 0.215 & 0.434 & 0.933 & 0.794 & 0.219 & 0.433 & 0.935 & 0.803 & 0.211 & 0.432 & 0.931 \\
\hline
\end{tabular}

Note: As defined in the previous section, $\mathrm{E}_{\mathrm{i}}$ stands for Efficiency Index, $\mathrm{C}_{\mathrm{i}}$, for Constraint Index, $\mathrm{H}_{\mathrm{i}}$ for Hierarchy Degree and $\mathrm{U}_{\mathrm{i}}$ for Direct and Indirect Efforts to establish links.

In general, the European Union presents high levels of efficiency (note that the efficiency index, $E_{\mathrm{i}}$, is around 0.8 , very close to 1 ) in the access to diverse information due to the existence of non-redundant relations and structural holes across the economic network. Over the period 2000-2007, the levels of efficiency have decreased while constraints have slightly increased. Such result suggests that the European market is a mature one with high levels of innovation diffusion. 
In the ICT sector, the mean efficiency score is similar to that observed for the rest of the economy. While this result implies that nowadays the intermediary role of the ICT sector does not differ much from that of the other productive sectors; results on the constraint index indicate that the ICT sector has fewer restrictions than the rest of the productive industries. Hence, the ICT sector is able to generate a network, that does not concentrate on single contacts (hierarchy), but has a large size with intermediate or/and undirected relations. In this sense, the undirected flows of the ICT sector are higher than those of the rest of the economy. Low hierarchy and large undirected relations suggest that ICT industries are key in the spread of "relevant" information and knowledge in the European economic network. Furthermore, it indicates that many industries get information from them. In addition, low constraints allow to establish diffusion processes quite independently from other sectors.

Within the ICT sector, the braches with the highest efficiency levels and the lowest constraints are wholesaling of machinery, equipment and supplies and medical, precision and optical instruments. As the European Commission states (2011) "these firms are reshaping their product portfolio, specializing and favoring lighter asset strategies, in particular by relying on leading-edge foundries capacities”. In contrast, computer and related activities is the branch with the lowest efficiency and the highest constraints. Such a result might be explained by the heterogeneity in the activities and firm's size: “Alongside multinational companies supplying consulting services, IT outsourcing services, business and non-business application software, there are thousands of software and computer services companies being mostly active on a national or local scale” (European Commission, 2011).

The non ICT sectors have more constraints, meaning fewer structural holes (Burt, 1992) compared to the ICT sector. A high level of constraints suggests that there are dense sector groups with high dependences. Hence, the non ICT sectors are strongly interconnected, and the impact of indirect relationships is moderated by the number of direct linkages.

All these imply that negative shocks in the economy have a limited impact over the European ICT sector compared to other economic sectors. Figures $\mathrm{n}^{\mathrm{o}} 1$ and 2 show the scatter plots between the constraint index and two measures of the economic output (gross value added and production, in Mio. EUR. current prices).

Figure $n^{0} 1$ shows the following negative linear relationship in the ICT sector: as the constraint index increases, the gross value added and/or production decreases via a fuzzy-firm linear rule. The variation in the economic output explained by constraints in the ICT sector is between $20 \%$ and $40 \%$. 
Figure $\mathrm{n}^{0} 2$ also shows a negative non linear relationship in the non ICT sectors: as the constraint index increases, the gross value added and/or production decreases at a nonconstant rate, reaching a value of zero for medium/ high values of the constraint index. The variation in the economic output explained by constraints in the non ICT sectors is quite low (between $9 \%$ and 18\%).

Overall, results show that the ICT sector not only has a strong capacity of growth but also its relational structure facilitates the development of the European economy without strong dependencies. This result is extremely important in the current economic crisis since it provides some key evidence for policy makers to design industrial policies aimed at overcoming economic difficulties.

Figure $n^{0}$ 1. Effects of Constraints over main economic indicators. ICT sectors
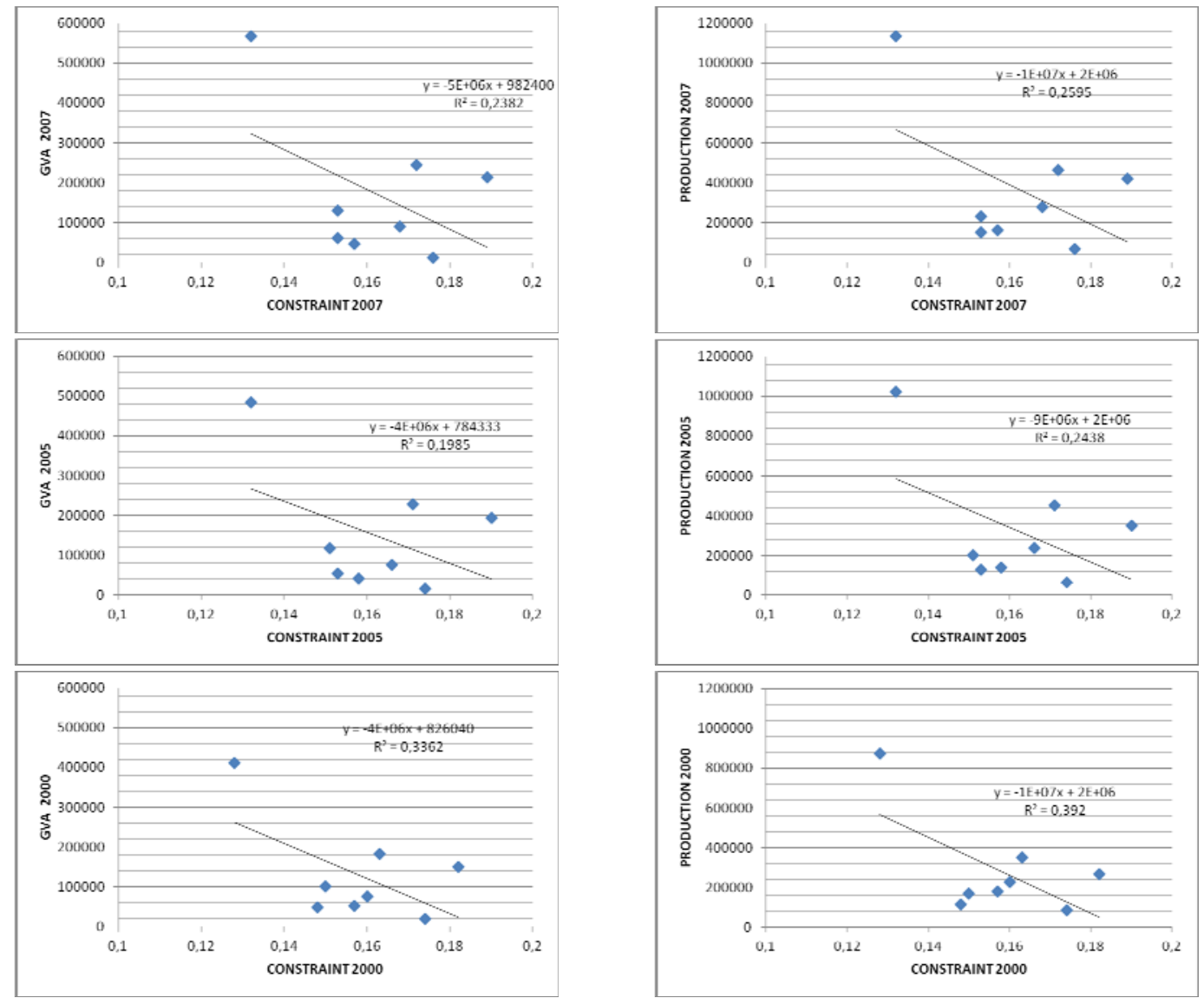
Figure $n^{0}$ 2. Effects of Constraints over main economic indicators. Non- ICT sectors
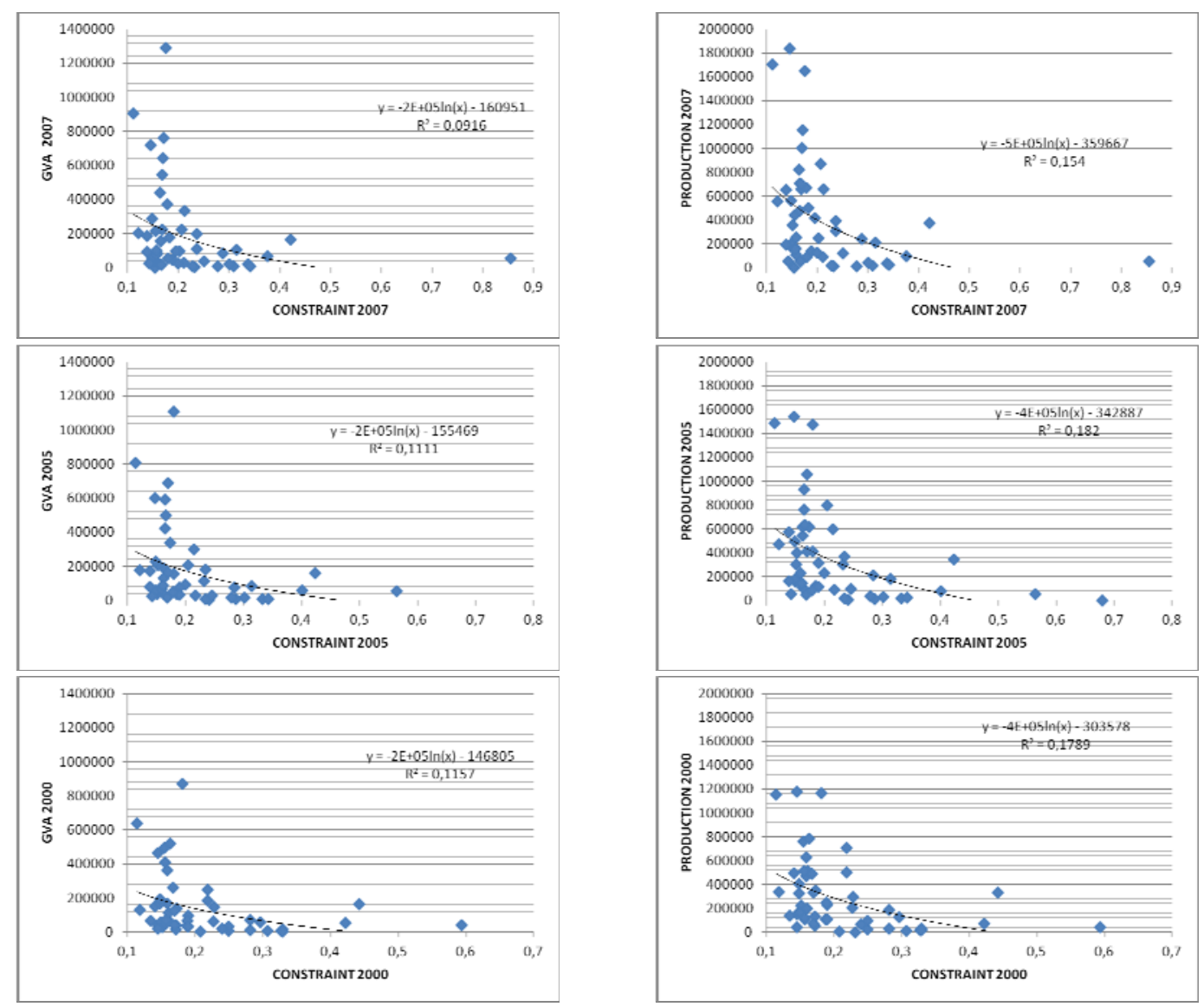

\section{Conclusions}

The economic structure is a vehicle for inducing cooperation and facilitating the process of innovation, technology diffusion and economic development. The relationships that industries establish within the economic network determine the potential advantages to gain from technological discontinuities (Utterback 1994). Obviously not all the linkages have the same importance in the spread of new ideas and opportunities. "The structural positions associated with the highest return lie between not within dense regions of relationships" (Walker, Kogut and Shan, 1997). These holes represent opportunities for broker information flows among firms or sectors (García et al., 2010). This paper presents a novel perspective on the ICT sector by using the structural holes concept. This methodology is based on the connections established in the economic network and their proximity, and thus allows to unveil the complexity, strength and weakness of the ICT structure.

Results show that the European ICT sector has a high level of efficiency with low dependences. The presence of structural holes in the network of contacts established by the ICT sector implies that this sector has access to diverse information. In contrast, the non ICT 
sectors tend to generate more homogenous information through their linkages and with larger dependences on other sectors. Therefore, the ICT sector is the main economic activity able to access to new potentially valuable resources and has advantages related informationexclusivity. Hence, this sector has the capacity to foster technological diffusion and innovation across the European Union. Regarding constraints, the low results obtained for the ICT sector indicate that negative shocks in the economy have a limited impact over this sector compared to the rest of industries. In fact, previous studies by the OECD (Mickoleit et al., 2009) and the European Commission (2011) have shown that the European ICT sector weather the crisis better than the rest of the economy.

The high efficiency levels of the ICT sector, in general, together with other services sectors, emphasize their role both as links between production blocks and as a the key in the fragmentation of productive chains. This fact might related to the changes driven by globalization and innovations in manufacturing patterns, such as JIT (Just-in-Time Delivery) and new business opportunities linked to telematics. The current patterns of production/distribution has been built by a competitive edge around the development of subcontracting systems, the exploration of modulation techniques, and the implementation of efficient vertical value chains (Hummels et al. 2001; Humphrey and Schmitz 2002; Jones and Kierzkowski 2005). 


\section{References}

Bernstein, J., Mohnen, P. (1998): “International R\&D spillovers between U.S. and Japanese R\&D intensive sectors”, Journal of International Economics, 44, pp. 315-338

Borgatti, S.P. (1997): “Structural holes: unpacking Burt's redundancy measures”, Connections, 20, pp. 35-38.

Bresnahan, T. and Trajtenberg, M. (1995): "General purpose technologies: Engines of growth?”, Journal of Econometrics, 65, 83-108.

Brynjolfsson. E., Hitt, L.N. (2000): "Beyond computation: Information technology, organizational transformation and business performance", The Journal of Economics Perspective, 14, pp. 23-48.

Burt, R.S (1992): Structural holes, Cambridge University Press, Cambridge.

Cronin, F.J., Colleran, E.K., Parker, E.B. and Gold, M.A. (1991): “Telecommunications Infrastructure and Economic Growth: An Analysis of Causality”, Telecommunications Policy, 15(6), pp. 529-535.

Dietzenbacher, E.; Romero, I. (2007): "Production Chains in an Interregional Framework: Identification by Means of Average Propagations Lengths”, International Regional Science Review, 30, pp. 362-383.

Dutta, A. (2001): "Telecommunications and Economic Activity: An analysis of Granger Causality”, Journal of Management Information Systems, 17, 4, pp. 71-95.

European Commission (2011): Digital Agenda Scoreboard 2011. The European ICT industry at the crossroad: economic crisis and innovation, in http://ec.europa.eu/information_society/digitalagenda/scoreboard/docs/pillar/research_innovation.pdf

Friedman, T. (2005): The World is Flat, New York: Farrar, Strauss and Giroux.

García Muñiz, A.S., Morillas, A., Ramos, C. (2010): "Spanish and European innovation diffusion: a structural hole approach in the input-output approach”, The Annals of International Regional Science, 44, 1, pp. 147-165.

Hummels D, Ishii J, Yi K (2001): “The nature and growth of vertical specialization in world trade”, Journal of International Economy, 54, 1, pp. 75-96. 
Humphrey, J., Schmitz H. (2002): "How does insertion in global value chains affect upgrading industrial clusters?”, Regional Studies, 36, 9, pp.1017-1027.

Jones, R.W.; Kierzkowski, H. (2005): "International fragmentation and the new economic geography”, North American Journal Economy Finance, 16, pp.1-10.

Jorgenson, D.; Stiroh, K. (1999): "Information technology and growth", American Economic Review, 89, 2, pp. 109-115.

Kretschmer, T. (2012), "Information and Communication Technologies and Productivity Growth: A Survey of the Literature", OECD Digital Economy Papers, No. 195, OECD Publishing. doi: 10.1787/5k9bh3jllgs7-en

Mickoleit, A.; Reimsbach-Kounatze, C.; Serra-Vallejo, C.; Graham Vickery, G.; WunschVincent, S. (2009): "The Impact of the Crisis on ICTs and their Role in the Recovery," OECD Digital Economy Papers, 163, OECD Publishing.

OECD (2003): A Proposed Classification of ICT Goods, OECD Working Party on Indicators for the Information Society, Paris.

OECD (2011): Guide to Measuring the Information Society, OECD, Paris.

Utterback, J.M. (1994): Mastering the dynamics of innovation, Harvard Business School Press, Boston.

Uzzi, B. (1996): "The sources and consequences of embeddedness for the economic performance of organizations: the network effect”, American Sociology Review, 61, pp. 674-698.

Walker, G.; Kogut, B.; Shan, W. (1997): "Social capital, structural holes and the formation of an industry network”, Organization Science, 8, 2, pp.109-125. 
Annex

Table A1. Structural holes Non ICT sectors

\begin{tabular}{|c|c|c|c|c|c|c|c|c|c|c|c|c|}
\hline & \multicolumn{4}{|c|}{2007} & \multicolumn{4}{|c|}{2005} & \multicolumn{4}{|c|}{2000} \\
\hline & $\mathbf{E}_{\mathbf{i}}$ & $\mathbf{C}_{\mathbf{i}}$ & $\mathbf{H}_{\mathbf{i}}$ & $\mathbf{U}_{\mathbf{i}}$ & $\mathbf{E}_{\mathbf{i}}$ & $\mathbf{C}_{\mathbf{i}}$ & $\mathbf{H}_{\mathbf{i}}$ & $\mathbf{U}_{\mathbf{i}}$ & $\mathbf{E}_{\mathbf{i}}$ & $\mathrm{C}_{\mathrm{i}}$ & $\mathbf{H}_{\mathbf{i}}$ & $\mathbf{U}_{\mathbf{i}}$ \\
\hline Agriculture. hunting & 0.808 & 0.421 & 0.773 & 0.826 & 0.807 & 0.423 & 0.774 & 0.826 & 0.806 & 0.442 & 0.794 & 0.799 \\
\hline Forestry. logging & 0.887 & 0.337 & 0.657 & 0.952 & 0.884 & 0.301 & 0.615 & 0.963 & 0.891 & 0.329 & 0.632 & 0.957 \\
\hline Fish and other fishing & 0.831 & 0.277 & 0.54 & 0.981 & 0.832 & 0.286 & 0.557 & 0.981 & 0.827 & 0.307 & 0.578 & 0.98 \\
\hline Coal and lignite; peat & 0.809 & 0.309 & 0.651 & 0.987 & 0.818 & 0.332 & 0.685 & 0.985 & 0.823 & 0.327 & 0.689 & 0.98 \\
\hline Crude petroleum and natural gas & 0.835 & 0.376 & 0.664 & 0.914 & 0.838 & 0.401 & 0.687 & 0.912 & 0.852 & 0.422 & 0.72 & 0.893 \\
\hline Uranium and thorium ores & 0.795 & 0.154 & 0.135 & 0.517 & 0.498 & 0.68 & 0.329 & 0.637 & 0.794 & 0.231 & 0.291 & 0.577 \\
\hline Metal ores & 0.818 & 0.232 & 0.474 & 0.995 & 0.826 & 0.24 & 0.483 & 0.995 & 0.825 & 0.208 & 0.411 & 0.996 \\
\hline Other mining and quarrying & 0.797 & 0.3 & 0.575 & 0.984 & 0.8 & 0.279 & 0.55 & 0.985 & 0.798 & 0.281 & 0.556 & 0.985 \\
\hline Food products and beverages & 0.824 & 0.206 & 0.514 & 0.773 & 0.826 & 0.205 & 0.514 & 0.771 & 0.829 & 0.218 & 0.558 & 0.744 \\
\hline Tobacco products & 0.73 & 0.228 & 0.456 & 0.987 & 0.721 & 0.234 & 0.469 & 0.987 & 0.737 & 0.249 & 0.472 & 0.988 \\
\hline Textiles & 0.827 & 0.159 & 0.351 & 0.94 & 0.83 & 0.162 & 0.363 & 0.935 & 0.831 & 0.171 & 0.398 & 0.914 \\
\hline Wearing apparel; furs & 0.818 & 0.211 & 0.482 & 0.944 & 0.819 & 0.217 & 0.495 & 0.939 & 0.829 & 0.249 & 0.565 & 0.92 \\
\hline Leather products & 0.798 & 0.167 & 0.355 & 0.995 & 0.797 & 0.168 & 0.355 & 0.995 & 0.798 & 0.171 & 0.364 & 0.994 \\
\hline $\begin{array}{l}\text { Wood and products of wood and } \\
\text { cork }\end{array}$ & 0.807 & 0.188 & 0.44 & 0.928 & 0.806 & 0.185 & 0.428 & 0.939 & 0.812 & 0.187 & 0.437 & 0.931 \\
\hline Pulp. paper and paper products & 0.812 & 0.149 & 0.319 & 0.973 & 0.811 & 0.15 & 0.322 & 0.973 & 0.813 & 0.151 & 0.329 & 0.968 \\
\hline Printed matter and recorded media & 0.746 & 0.202 & 0.48 & 0.968 & 0.747 & 0.2 & 0.47 & 0.968 & 0.756 & 0.19 & 0.445 & 0.963 \\
\hline Coke. refined petroleum & 0.824 & 0.151 & 0.327 & 0.907 & 0.826 & 0.151 & 0.334 & 0.901 & 0.83 & 0.151 & 0.341 & 0.886 \\
\hline Chemicals. chemical products & 0.811 & 0.139 & 0.307 & 0.941 & 0.811 & 0.139 & 0.309 & 0.942 & 0.809 & 0.14 & 0.316 & 0.941 \\
\hline Rubber and plastic products & 0.798 & 0.159 & 0.328 & 0.963 & 0.8 & 0.158 & 0.328 & 0.963 & 0.799 & 0.16 & 0.335 & 0.961 \\
\hline Other non-metallic mineral products & 0.756 & 0.287 & 0.645 & 0.931 & 0.756 & 0.284 & 0.639 & 0.933 & 0.758 & 0.281 & 0.638 & 0.933 \\
\hline Basic metals & 0.821 & 0.195 & 0.441 & 0.909 & 0.824 & 0.19 & 0.425 & 0.913 & 0.822 & 0.188 & 0.418 & 0.921 \\
\hline $\begin{array}{l}\text { Fabricated metal products. except } \\
\text { machinery and equipment }\end{array}$ & 0.804 & 0.183 & 0.406 & 0.907 & 0.806 & 0.179 & 0.392 & 0.914 & 0.809 & 0.173 & 0.381 & 0.918 \\
\hline Machinery and equipment n.e.c. & 0.796 & 0.168 & 0.364 & 0.943 & 0.8 & 0.162 & 0.348 & 0.946 & 0.802 & 0.159 & 0.341 & 0.947 \\
\hline $\begin{array}{l}\text { Motor vehicles. trailers and semi- } \\
\text { trailers }\end{array}$ & 0.812 & 0.165 & 0.328 & 0.943 & 0.814 & 0.162 & 0.323 & 0.94 & 0.811 & 0.161 & 0.321 & 0.943 \\
\hline Other transport equipment & 0.817 & 0.149 & 0.295 & 0.98 & 0.82 & 0.148 & 0.294 & 0.98 & 0.825 & 0.145 & 0.288 & 0.977 \\
\hline $\begin{array}{l}\text { Furniture; other manufactured } \\
\text { goods n.e.c. }\end{array}$ & 0.807 & 0.15 & 0.306 & 0.973 & 0.807 & 0.148 & 0.302 & 0.973 & 0.81 & 0.149 & 0.311 & 0.969 \\
\hline Secondary raw materials & 0.823 & 0.342 & 0.648 & 0.98 & 0.83 & 0.343 & 0.654 & 0.977 & 0.829 & 0.329 & 0.639 & 0.98 \\
\hline $\begin{array}{l}\text { Electrical energy. gas. steam and } \\
\text { hot water }\end{array}$ & 0.834 & 0.121 & 0.245 & 0.94 & 0.834 & 0.121 & 0.24 & 0.945 & 0.838 & 0.118 & 0.23 & 0.945 \\
\hline $\begin{array}{l}\text { Collected and purified water. } \\
\text { distribution services of water }\end{array}$ & 0.807 & 0.143 & 0.282 & 0.995 & 0.81 & 0.142 & 0.274 & 0.995 & 0.807 & 0.145 & 0.29 & 0.996 \\
\hline Construction work & 0.805 & 0.145 & 0.344 & 0.871 & 0.805 & 0.147 & 0.347 & 0.873 & 0.81 & 0.145 & 0.345 & 0.869 \\
\hline $\begin{array}{l}\text { Trade. maintenance and repair } \\
\text { services }\end{array}$ & 0.794 & 0.155 & 0.331 & 0.964 & 0.799 & 0.152 & 0.321 & 0.965 & 0.804 & 0.148 & 0.31 & 0.967 \\
\hline Retail trade services. & 0.779 & 0.164 & 0.376 & 0.957 & 0.78 & 0.165 & 0.373 & 0.959 & 0.785 & 0.159 & 0.361 & 0.962 \\
\hline Hotel and restaurant services & 0.78 & 0.212 & 0.463 & 0.942 & 0.782 & 0.214 & 0.471 & 0.941 & 0.784 & 0.218 & 0.482 & 0.939 \\
\hline $\begin{array}{l}\text { Land transport; transport via } \\
\text { pipeline services }\end{array}$ & 0.815 & 0.149 & 0.34 & 0.936 & 0.815 & 0.148 & 0.336 & 0.936 & 0.814 & 0.148 & 0.339 & 0.939 \\
\hline Water transport services & 0.818 & 0.251 & 0.556 & 0.97 & 0.818 & 0.246 & 0.547 & 0.973 & 0.829 & 0.24 & 0.545 & 0.978 \\
\hline
\end{tabular}


Table A1. Structural holes Non ICT sectors (cont.)

\begin{tabular}{|c|c|c|c|c|c|c|c|c|c|c|c|c|}
\hline & \multicolumn{4}{|c|}{2007} & \multicolumn{4}{|c|}{2005} & \multicolumn{4}{|c|}{2000} \\
\hline & $\mathbf{E}_{\mathbf{i}}$ & $\mathbf{C}_{\mathbf{i}}$ & $\mathbf{H}_{\mathbf{i}}$ & $\mathbf{U}_{\mathbf{i}}$ & $\mathbf{E}_{\mathbf{i}}$ & $\mathbf{C}_{\mathbf{i}}$ & $\mathbf{H}_{\mathbf{i}}$ & $\mathbf{U}_{\mathbf{i}}$ & $\mathbf{E}_{\mathbf{i}}$ & $\mathbf{C}_{\mathbf{i}}$ & $\mathbf{H}_{\mathbf{i}}$ & $\mathbf{U}_{\mathbf{i}}$ \\
\hline Air transport services & 0.822 & 0.199 & 0.446 & 0.967 & 0.822 & 0.19 & 0.428 & 0.972 & 0.82 & 0.19 & 0.433 & 0.967 \\
\hline $\begin{array}{l}\text { Domporting and auxiliary transport } \\
\text { services; travel agency services }\end{array}$ & 0.799 & 0.166 & 0.389 & 0.906 & 0.796 & 0.17 & 0.399 & 0.912 & 0.797 & 0.169 & 0.396 & 0.914 \\
\hline Financial intermediation & 0.789 & 0.178 & 0.407 & 0.925 & 0.79 & 0.173 & 0.396 & 0.922 & 0.791 & 0.167 & 0.389 & 0.932 \\
\hline $\begin{array}{l}\text { Insurance and pension funding } \\
\text { services. }\end{array}$ & 0.779 & 0.237 & 0.501 & 0.916 & 0.781 & 0.232 & 0.489 & 0.917 & 0.781 & 0.227 & 0.482 & 0.924 \\
\hline $\begin{array}{l}\text { Services auxiliary to financial } \\
\text { intermediation }\end{array}$ & 0.83 & 0.315 & 0.576 & 0.892 & 0.823 & 0.314 & 0.573 & 0.899 & 0.825 & 0.296 & 0.55 & 0.912 \\
\hline Real estate services & 0.778 & 0.175 & 0.402 & 0.924 & 0.774 & 0.18 & 0.412 & 0.92 & 0.772 & 0.181 & 0.419 & 0.922 \\
\hline Research and development services & 0.813 & 0.139 & 0.283 & 0.982 & 0.818 & 0.138 & 0.279 & 0.981 & 0.822 & 0.134 & 0.263 & 0.982 \\
\hline Other business services & 0.846 & 0.111 & 0.229 & 0.874 & 0.845 & 0.114 & 0.239 & 0.877 & 0.842 & 0.114 & 0.244 & 0.883 \\
\hline $\begin{array}{l}\text { Public administration and defence } \\
\text { services; compulsory social security } \\
\text { services }\end{array}$ & 0.777 & 0.17 & 0.404 & 0.965 & 0.785 & 0.165 & 0.383 & 0.963 & 0.794 & 0.154 & 0.347 & 0.965 \\
\hline Education services & 0.782 & 0.168 & 0.373 & 0.984 & 0.783 & 0.166 & 0.355 & 0.984 & 0.795 & 0.155 & 0.326 & 0.985 \\
\hline Health and social work services & 0.777 & 0.171 & 0.381 & 0.965 & 0.776 & 0.17 & 0.372 & 0.965 & 0.783 & 0.163 & 0.349 & 0.969 \\
\hline $\begin{array}{l}\text { Sewage and refuse disposal } \\
\text { services. sanitation and similar } \\
\text { services }\end{array}$ & 0.787 & 0.157 & 0.342 & 0.987 & 0.787 & 0.159 & 0.346 & 0.987 & 0.786 & 0.156 & 0.339 & 0.988 \\
\hline $\begin{array}{l}\text { Membership organisation services } \\
\text { n.e.c. }\end{array}$ & 0.776 & 0.18 & 0.411 & 0.994 & 0.779 & 0.178 & 0.399 & 0.994 & 0.783 & 0.169 & 0.378 & 0.994 \\
\hline $\begin{array}{l}\text { Recreational. cultural and sporting } \\
\text { services }\end{array}$ & 0.724 & 0.237 & 0.569 & 0.975 & 0.724 & 0.234 & 0.555 & 0.975 & 0.73 & 0.228 & 0.545 & 0.976 \\
\hline Other services & 0.778 & 0.157 & 0.364 & 0.993 & 0.774 & 0.161 & 0.374 & 0.993 & 0.78 & 0.156 & 0.356 & 0.993 \\
\hline $\begin{array}{l}\text { Private households with employed } \\
\text { persons }\end{array}$ & 0.606 & 0.854 & 0.855 & 0.705 & 0.662 & 0.564 & 0.706 & 0.648 & 0.663 & 0.593 & 0.727 & 0.624 \\
\hline MEAN & 0.798 & 0.215 & 0.434 & 0.933 & 0.794 & 0.219 & 0.433 & 0.935 & 0.803 & 0.211 & 0.432 & 0.931 \\
\hline
\end{tabular}

Note: As defined in the previous section, $\mathrm{E}_{\mathrm{i}}$ stands for Efficiency Index, $\mathrm{C}_{\mathrm{i}}$, for Constraint Index, $\mathrm{H}_{\mathrm{i}}$ for Hierarchy Degree and $\mathrm{U}_{\mathrm{i}}$ for Direct and Indirect Efforts to establish links. 


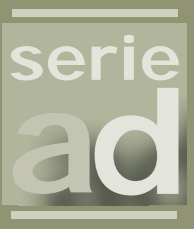

\section{I vie}

Guardia Civil, 22 - Esc. 2, 1음

46020 Valencia - Spain

Phone: +34 963190050

Fax: +34 963190055

Website: www.ivie.es

E-mail: publicaciones@ivie.es 